Aletheia, vol. 10, $\mathrm{n}^{\circ}$ 20, e042, junio-noviembre 2020. ISSN 1853-3701

Universidad Nacional de La Plata

Facultad de Humanidades y Ciencias de la Educación

Maestría en Historia y Memoria

\title{
Editorial
}

Ana M. Barletta

\section{Estimadxs lectorxs,}

Con gran satisfacción, queremos abrir esta nueva edición celebrando nuestro número 20 que, al completar el volumen 10, nos marca un aniversario: los 10 años de la revista que, regularmente, ha salido con sus dos números anuales. Nos hubiera gustado mucho celebrarlxs con un encuentro presencial pero, seguimos sin poder reunirnxs. Ya lo haremos, cuando la pandemia ceda y podamos volver a juntarnxs. No obstante, seguimos trabajando y es muy notable la vitalidad de este colectivo que, contra viento y marea, sigue produciendo números sugestivos, como éste que presentamos hoy, que reúne colaboraciones muy conectadas con los tiempos que vivimos. Entre los múltiples aspectos que podríamos festejar en este aniversario está el modo en que la revista ha sabido organizar y reunir colectivamente a maestrandxs y graduadxs en torno a una carrera y a una Facultad que valora nuestros temas y que apostó a sostener el desafío de construcción de un campo novedoso y crispado, corrido de los encuadramientos más canónicos de las ciencias sociales y las humanidades con las que ha logrado vínculos virtuosos dentro de las problemáticas de la Historia y la Memoria. Trasnacionalidad y nuevas generaciones son tal vez los aspectos más destacables que se han consolidado en estos 10 años, palpable en la constitución de su staff más estable y en sus colaboradores permanentes, en vínculo con una carrera, la Maestría, que puede albergar estas múltiples perspectivas dentro de una experiencia político-educativa en nuestra región latinoamericana: estudiantes, graduadxs, profesores, autores, editores, militantes...

Una idea estructurante de nuestro proyecto original, el enfoque particularmente politizado, se pone en juego en este número de forma muy visible en el Dossier "Chile, hasta que la dignidad se haga costumbre. Movilización social, proceso constituyente y horizontes de posibilidad post 18 de octubre", coordinado por Claudio Alvarado Lincopi y Javiera Robles Recabarren (ambxs Magisters en Historia y Memoria), colegas chilenxs que nos propusieron -al calor de los acontecimientos de la explosión callejera de fines del año pasadoorganizar este dossier pensando en la urgencia de la intervención desde la academia como interpretación, construcción de conocimiento, difusión y acompañamiento de una revuelta que desde el inicio instalaba el peso del tiempo histórico y la memoria en el centro del combate: "NO SON 30 PESOS, SON 30 ANOS”, fue la consigna aglutinante de tanto reclamo. Y se pusieron a armarlo y lo lograron contra reloj en plena aceleración del tiempo político, del tiempo histórico y, luego, en la extraña suspensión temporal de la pandemia. Una experiencia nueva para nuestra revista que permite que esos acontecimientos estén documentados hoy en este $\mathrm{N}^{\circ} 20$. En los escasos tiempos de producción, nos lo iban diciendo: "Chile no nos deja descansar" (...) “El dossier ha costado” (...) “Sentarse a escribir está difícil”. Fue un gran desafío desde un presente acuciante, aportar también desde la historia y la memoria. Y lograron un producto muy evocador.

La dura realidad de desigualdades y de opresión que esta coyuntura de protestas y pandemias visibilizó, se revela nítidamente en los artículos del dossier: el movimiento feminista chileno, el socioambiental, los colectivos artísticos, la ciudad y sus marcas, los movimientos indígenas disputan en estas páginas sentidos del pasado, del presente y del futuro, exponiendo -en formas muy evidentes al calor del acontecimiento crítico- que los sólidos fundamentos macroeconómicos en los que se propagandizaba el modelo chileno de desarrollo ocultaban una desigualdad alarmante. Memorias del hambre, de la represión, de los allanamientos pero también de las resistencias, de la organización, de la solidaridad, memorias subterráneas de quienes vivieron el golpe y la dictadura militar están presentes en los relatos cotidianos de la sublevación. 
Tiempo y espacio interpelados, y también la historiografía demandada por la irrupción de las mujeres y otrxs nuevxs sujetxs, y por la apropiación del espacio con la intención de grabar nuevas marcas y demoler o hacer desaparecer las viejas, entre la multitud: irrupción de las memorias sociales de lxs vencidxs buscando genealogías políticas para nuevas memorias y nuevos relatos nacionales. Renombramiento de lugares, desmonumentalización, borramientos de censura gubernamental, pelea en las calles por la huella nueva, estampada por la protesta. Dice mucho este dossier también en sus copiosas imágenes del estallido, de esa memoria subversiva que a la vez que critica el modelo, que distaba de ser el "oasis" pregonado, estimula el recuerdo de lo ya acontecido: "revienta el pasado", "explota la memoria". "Inesperado en su magnitud, no en sus contenidos”, dice en el dossier Carmen Pinto Luna, otra de nuestras Magisters y, en esa magnitud, está la enorme creatividad reflejada en los mismos artículos y en la sección Prácticas Artístico-Culturales que acompaña magníficamente la apuesta de este número.

En esa sección, la exhaustiva reseña "De la urgencia a la solidaridad. Acciones de visibilidad y apoyo al estallido social en Chile" de nuestra Magister Melina Jean Jean, recoge las intervenciones realizadas por maestrandxs y graduadxs de Historia y Memoria, junto a Aletheia y a la Prosecretaría de DDHH y a programas y equipos de investigación sobre historia reciente de nuestra Facultad. Resulta sugestivo recorrer los links para conectarnos con todas las actividades de fines del año pasado cuando nos interpeló la revuelta chilena y se lanzó el activismo académico: encuentros extraordinarios, de construcción de lazos con lxs compañerxs de Chile y también de Colombia, más el acto de diciembre en el rectorado de nuestra universidad "Solidaridad activa con el pueblo de Chile. Primera Jornada de acción urgente". Este evento fue producto de un esfuerzo enorme de pensamiento y producción, en el momento mismo en que se producían los sucesos en Chile, para reunir presencias y virtualidades. Esa urgencia y ese espontaneísmo se refleja en lo artesanal de esas filmaciones que reproducimos acá, para seguir pensando con lxs colegas que nos acompañaron y para seguir conectándonos con los imperativos de la revuelta. Fue muy comprometida la decisión de hacerlo y también de filmarlo así, artesanalmente, para poder conservarlo. Un logro increíble de la colega Florencia Larralde Armas (otra de nuestras Magisters) que sostuvo firme su celular durante todo el evento filmando y transmitiendo en vivo a través de la página de Facebook de la Maestría. Se podrá entrar y salir para ver cada link: las manifestaciones estéticas, los videos, las fotografías que nos llegaron de Chile y las palabras reveladoras de lxs colegas, muchas de ellas acompañadas de imágenes fascinantes de la insurgencia que, junto a las voces de lxs investigadorxs, fueron lxs grandes protagonistas de la escena.

Me gustaría nombrar y reconocer a cada unx. Pero sólo menciono acá a Cora Gamarnik a quien le agradecemos por haber insistido para realizar esta intervención como una apuesta para entender desde adentro de Chile, a partir de fotografías, reflexiones y testimonios "calientes" dentro de esa superabundancia de imágenes que daban cuenta de la "espectacularidad de la protesta", construida como estrategia de visualidad ante la urgente necesidad de mostrar lo que estaba sucediendo.

La sección Artículos (que nos llegan siempre, esta vez desde la Universidad de Buenos Aires, la Universidad Nacional Arturo Jauretche, la Universidad de la República de Uruguay y el Núcleo de Estudios Judíos del IDES) tiene en común la reflexión sobre la necesaria actualización de las políticas de memoria, en relación con el archivo, al testigo, al vínculo con la política gubernamental, a la construcción de memoriales y a la trasmisión. Increíblemente, acá también tenemos alertas, urgencias, tiempos apremiantes para la academia: que no se vuelva rígida la memoria oficial, que podamos escuchar memorias subterráneas, que podamos registrar los testimonios de lxs protagonistas de las luchas y resistencias de 40 años atrás, antes de que sea tarde para obtenerlas... Martina Eva García, desde el Uruguay, activa este imperativo para poder contar con lo no escuchado aún, pero no como meros documentos para el trabajo académico, sino como oportunidad para pronunciarse. Otra vez el tiempo...

La preocupación por ser oída y escuchada es el grito desesperado de María Herrera Magdaleno, recogido en la Entrevista de este número, realizada por María Emilia Nieto y por Carlos Gutiérrez Rodríguez (que acaba de defender su tesis de Maestría en Historia y Memoria en plena pandemia, desde Colombia). El 
testimonio de María, madre de cuatro hijxs desaparecidxs en México y referente de la resistencia a la violencia generalizada y las violaciones a los derechos humanos en su país, es muy conmovedor. Tan empático con nuestras Madres, con sus parecidas y diferentes búsquedas de lxs hijxs desaparecidxs, y con el registro de lo femenino de esta lucha. María percibe una sociedad deshumanizada ante su grito, que es el nuestro: $i$ Vivxs se lxs llevaron, vivxs lxs queremos!

Entonces, ¿hay lugares de escucha? Hay más voces que lugares, podríamos decir con Alessandro Portelli (como recuerdan Ingrid Jacek y Julieta Sahade en la Conferencia "Archivo oral de la Comisión Provincial por la Memoria. Memorias encontradas: el archivo y el testigo”). Esta conferencia que ofrecemos hoy es la segunda parte del evento de septiembre 2019, compartido con el amigo italiano, que publicamos en nuestro número anterior. Justamente, es la Comisión Provincial por la Memoria de la Provincia de Buenos Aires y el activismo vinculado a su enorme Archivo, quien se ha constituido en uno de esos lugares, en un vehículo para poner esa escucha al servicio de distintxs actores sociales. En esta oportunidad, algunos relatos de viejxs militantes de la resistencia peronista, de ex detenidxs y familiares de desaparecidxs en la última dictadura militar podrán verse y escucharse en los links que nos conducen a sus propias imágenes y palabras. Enfatizamos el valioso trabajo de este Archivo para seguir “encontrando" voces y narraciones, incluso de grandes referentes de la militancia política platense, personas que recién se han reconocido como víctimas por primera vez en 2017 y que provienen de barrios populares de Berisso, Ensenada y el Conurbano.

No quiero dejar de mencionar las Reseñas de Libros recientes y Reseña de Tesis de Maestría del novel Magister ecuatoriano Marlon Fabricio Hidalgo Méndez como, asimismo Reseña de una muestra de fotografías "Ráfagas de aire, formas de habitar los sitios de memoria”, curada por Cora Gamarnik y Florencia Larralde Armas - expuesta en el Museo de Arte y Memoria (MAM) de La Plata.

Y nuestra imagen de tapa: El Negro Matapacos, el popular perro que se convirtió en un símbolo del estallido social indiscutido entre lxs chilenxs, imagen creada por el artista callejero Caiozzama, en el mes de noviembre en Santiago de Chile que corona la sintonía con las narrativas de la sublevación.

Algo extraordinario de la contestación generalizada de octubre es que se percibió a sí misma como consecuencia del pasado exigiendo implícitamente una nueva valoración de éste que reclama ser reinterpretado, a partir del conjunto de demandas y puentes tendidos hacia atrás. Las palabras de Traverso (siempre Enzo con nosotrxs) recordadas en el artículo de Elías Sánchez (otro Magister en Historia y Memoria) se vuelven muy tentadoras en esta coyuntura y son inspiradoras, como desafío, para volver a pensar un proyecto de transformación radical de la sociedad, en una época no revolucionaria.

Cuando leía este Dossier tuve en mi mente un libro que adoro, Un día de octubre en Santiago de Carmen Castillo Echeverría. La autora intenta reconstruir los acontecimientos convergentes que el sábado 5 de octubre de 1974 confluyeron en la emboscada de la DINA que permitió a los militares chilenos matar a Miguel Enríquez, jefe del M.I.R. Movimiento de Izquierda Revolucionaria, casi un año después del derrocamiento de Salvador Allende. Ella es una sobreviviente directa de ese acontecimiento a través del cual comenzó una reflexión sobre las formas de luchar en tiempos diferentes, luchar por las ideas revolucionarias desde múltiples perspectivas. El libro es un ejercicio de memoria colectiva sobre ese día de octubre en Santiago. Carmen estuvo también en medio de las protestas de 2019, conectando con el espíritu de su libro de 20 años antes, un libro sobre la fraternidad revolucionaria, con una audaz voluntad de diálogo intergeneracional, con mucha empatía hacia lxs vencidxs y lxs luchadores. Ahora solo quiero rescatar estas maravillosas palabras de su prólogo:

El tiempo no es lineal. Eso me lo enseñaron los indígenas.

No me ato, entonces, a la forma que tomó la lucha en un momento determinado, no busco ser la caricatura de lo que fui. Pienso que si me repito por conformismo, por convención, culpa o comodidad, estoy siendo infiel con la esencia revolucionaria. La fidelidad no es con el pasado sino con algo que es siempre presente, presente encarnado en todos aquellos cuya energía de vida es el deseo, deseo profundo y vital de justicia. Ir creando, inventando como hacer camino, darse colatazos y volar, los dos. 
Siento que estamos menos solos, que algo resuena en el mundo otra vez. Ese quejido de la vida de Miguel se encarna en la resistencia de los indígenas de Chiapas, de los mapuches, de las madres de los desaparecidos de los pobladores sin casa, de las familias de ejecutados y presos, de los jóvenes poetas, de los sin tierra, de los sin casa, de los indocumentados... Luchas democráticas por la democracia, por un mundo donde quepan muchos mundos, como dicen los zapatistas.

No sabemos qué va a suceder, pero escuchamos voces, risas, pasos, un murmullo en movimiento que sacude la desesperanza, abate el desaliento, acaba con la melancolía (Castillo Echeverría, 1999, p. 10-11).

Reescritura de la Historia, memoria y creatividad políticas es lo que tenemos en este número con consignas urgentes que interpelan a nuestras disciplinas, a la construcción de conocimiento y a nuestra inserción académica e institucional.

Finalmente, celebramos estos 10 años de trabajo juntxs; seguiremos apostando a mantener la vitalidad de este equipo que se ha consolidado en el diálogo y la construcción colectiva con notable entusiasmo, aportando pensamiento y dedicación al fortalecimiento de un campo renovador de las ciencias sociales y humanas. Un saludo muy afectuoso para todas las camadas que formaron y siguen formando parte de este apasionado proyecto.

Ana M. Barletta

Coordinadora de la Maestría en Historia y Memoria
Septiembre 2020

\section{ReFERENCIAS}

Castillo Echeverría, C. (1999). Un día de octubre en Santiago. Santiago de Chile: LOM Ediciones. 